\title{
LA ESFERA EN LA OBRA DE ROBERTO MONTENEGRO: UN ANÁLISIS ICONOGRÁFICO
}

Julieta Ortiz Gaitán

Un elemento iconográfico constante en la obra pictórica de Roberto Montenegro es la esfera, elemento que aparece reiteradamente ya sea en la obra de caballete, en la obra gráfica o en algunos de los murales realizados por el pintor tapatío. Estas esferas aparecen indistintamente, como brillantes globos que reflejan el entorno y rondan a los personajes de Montenegro, a veces evocando redondos frutos sostenidos en las manos, en otras, semejando enormes burbujas de cristal cuya presencia parece un tanto enigmática.

A esto hay que agregar otro planteamiento pictórico empleado por Montenegro, consistente en englobar el espacio representado en una gran esfera, dentro de la cual se estructura el mundo del pintor y su propia imagen. Dentro de este rubro están sus múltiples autorretratos.

El círculo y la esfera son imágenes presentes en la vida del hombre, desde el vientre materno, hasta la redondez imperceptible --pero incuestionable- del planeta en que habita. Pleno de significados, el círculo es empleado por Roberto Montenegro en dos esquemas diferenciados:

1. Esferas brillantes, a veces sostenidas en las manos de los personajes, $y$ otras englobando el espacio; y

2. Esferas opacas, que cumplen una función puramente decorativa, para subrayar el gesto gracioso de la mano o de la postura del modelo.

Pero vayamos al análisis de la esfera como motivo iconográfico en las representaciones pictóricas del arte occidental, visto de una manera muy sumaria, para después abordar la obra de Montenegro con la finalidad de poder establecer ciertas correspondencias que fundamenten la presencia de dichos elementos esféricos.

\section{LA ESFERA $=$ LO PERFECTO}

Dentro de las formas geométricas empleadas por el hombre en sus representaciones pictóricas, el círculo ha sido considerado sinónimo de perfección desde las culturas de la antigüedad. El círculo es en sí mismo perfecto por ser una continuidad, una figura que no tiene principio ni fin. El culto primitivo a los astros, principalmente al sol y a la luna, establece 
una relación ideológica entre el concepto mágico-religioso de divinidad y la forma geométrica circular. El culto al sol era primordial en las prácticas religiosas del antiguo Egipto y de los pueblos mesoamericanos del Altiplano central, por citar sólo dos ejemplos.

No es difícil detectar la presencia de elementos circulares en la evolución de la arquitectura y de la pintura en el arte occidental. El Partenón, al igual que otros templos griegos de la época clásica, está circunscrito en un medio círculo; el panteón romano de Agripa, lugar de todos los dioses, se cubre con una colosal cúpula de media naranja que mide $42 \mathrm{~m}$ de diámetro por $42 \mathrm{~m}$ de altura; en la arquitectura románica y gótica, los grandes rosetones no sólo iluminan con un haz de luz multicolor el místico interior de las catedrales, sino que ocupan un lugar prominente en las fachadas que evidencia su importancia y alude a la presencia de Dios. Las cúpulas grandiosas de la catedral de Florencia y de San Pedro en Roma, son elementos arquitectónicos esféricos tomados de la antiguiedad romana, que adquieren proporciones magníficas durante el Renacimiento italiano, y que continúan durante el barroco, el neoclásico y el eclecticismo de fin de siglo. Los remates esféricos proliferan durante el neoclásico, en fachadas, torres y balaustres, a veces sobre bases piramidales, y otras como simples remates. ${ }^{1}$

Respecto a sus connotaciones ideológicas, Ferguson afirma en su tratado sobre iconología en el arte cristiano, que el círculo es "el símbolo universal de la eternidad y la vida perdurable. Como emblema divino representa, no sólo la perfección de Dios, sino su Eternidad".?

Dentro de la representación pictórica, son de gran interés las imágenes relacionadas con esferas o círculos que menciona Césare Ripa en su recopilación sobre imaginería barroca, realizada a principius del siglo XVI. ${ }^{3}$ Ripa registra once alegorías con sus respectivos grabados, que sirven para la catalogación iconográfica de la obra de Montenegro, y que se describen a continuación:

\section{Principium (El Principio)}

Figura femenina vestida de blanco (pureza de la esencia de Dios) parada en medio de un paisaje rocoso y desierto; sostiene dos globos azules en

${ }^{1}$ Cuyso de Iconografía, Arq. Manuel González Galván, División de Estudios de Posgrado, Facultad de Filosofía y Letras, U.N A M

${ }^{2}$ George Ferguson, Signas y Simbolos en el Arte Cristiano Buenos Aires, Ed Hermes, p. 221.

${ }^{3}$ Césare Ripa, Baroque and Rococó Pictorial Imagery, Ibe 1758-60 Hertel Edition of Ripa's "Iconologia". With 200 engraved illustrations. Introduction by Edwatd A Maser. Dover Publications Inc, New York. 
sus manos, de los cuales surgen llamas al igual que de su cabeza. Azul es el color que significa eternidad y el globo es su símbolo. Las tres llamas que irradian de la cabeza significan la Trinidad (Alegoría No, 4). Figura 1.

\section{Annus (El Año)}

Hombre de edad, con alas, sosteniendo en una mano el antiguo símbolo del año o del tiempo: una serpiente mordiéndose su propia cola; en la otra mano sostiene un clavo en alusión a la costumbre romana antigua de clavar un clavo cada año nuevo en la pared del templo; descansa sobre un globo en un pedestal, símbolo del universo o de la perfecta continuidad (Alegoría No. 17).

\section{Aeternitas (Eternidad)}

La invención de Francesco Barberini en esta alegoría, como afirma Ripa, sugiere la naturaleza circular de la eternidad. Las dos esferas que la figura femenina sostiene son de oro, un símbolo de la incorruptibilidad; su cuerpo azul y cubierto de estrellas, representa los cielos (Alegoría No. 20) .

\section{Pompa Paupertatis (Falso Esplendor)}

La personificación presenta a una joven con los ojos vendados, llevando una expresión de soberbia en el rostro. Porta corona y viste con riqueza un manto rcjo, bajo el cual se ve la vestimenta raída y de color cenizo. E1 rojo es, en este caso, el color del orgullo y la ambición; el gris representa la pobre realidad bajo la ostentación. La mujer sostiene un pavo real, símbolo tradicional de la vanidad y la gran esfera en la que está parada simboliza la inestabilidad y la frágil base del orgullo y la ambición (Alegoría No. 29).

\section{Veritas (Verdad)}

Una mujer desnuda, modestamente cubierta con un manto, sostiene un sol en la mano y un libro abietto con una palma entre sus hojas en la otra. Descansa un pie en un globo terráqueo, simbolizando a la verdad como sol radiante, fuente de luz inagotable y dominando sobre el mundo (Alegoría No. 50).

\section{Submissa Mens (Humildad)}

Una mujer descalza con la mirada baja y los brazos cruzados frente al pecho; vestida sencillamente en blanco y gris, sostiene una esfera en 
la mano derecha. A sus pies están una corona y un borrego. La esfera representa la idea de que, al igual que una pelota tirada al aire tiene que bajar otra vez, la persona humilde está consciente de esto no importa qué tan alto se halle colocada. La corona a sus pies simboliza el desapego a los signos externos de riqueza y el cordero la humildad de Cristo (Alegoría No. 86). Figura 2.

\section{Historia (Historia)}

Una mujer vestida de blanco escribe sobre un libro que reposa encima de la figura alada del tiempo, representado como saturno. A los pies de la mujer están una esfera, un rollo o pergamino enrollado, otro libro abierto y una cornucopia vacía. Saturno se come una piedra, en una mano sostiene una hoz y la serpiente enrollada del tiempo y la eternidad (Alegoría No. 122).

\section{Fortuna (Fortuna)}

Una mujer desnuda y alada, con los ojos vendados, parada sobre un pie en una gran esfera, sostiene una cornucopia con cada brazo. Sobre su cabeza otra esfera cubierta con estrellas está suspendida. Su frágil posición hace que se balancee en la esfera ya que es inestable y cambiante. Las estrellas están en movimiento continuo e influyen de modo inexorable en la fortuna de los hombres (Alegoría No. 152).

\section{Providentia Divina (Divina Providencia)}

Se representa la escena de la hija del faraón rescatando a Moisés de las aguas del Nilo. En el cielo se ve la figura alegórica de una mujer reclinada sobre una esfera; en una mano sostiene un cetro con el triángulo que contiene el ojo divino y en la otra, dos llaves. A su lado una cornucopia vierte su abundancia en frutos y al otro lado un amorcillo sujeta un timón (Alegoría No. 162).

\section{Scientia (Ciencia o Conocimiento)}

Una mujer sentada, con alas en la cabeza, sostiene en una mano un espejo y en la otra un triángulo y una esfera. La ciencia se prueba contiene impedimentos para moverse libremente (Alegoría No. 188). Figura 3.

\section{Philosophia (Filosofía)}

Una mujer con la cabeza alada, se para sobre un globo y sostiene con la cabeza el globo del universo (Alegoría No. 189). 
De esta serie de alegorías encontramos que la esfera tiene varias connotaciones en su representación pictórica, las cuales se podrían esquematizar de la siguiente manera:

\section{Dios = Eternidad, perfección, infinito.}

Su contraparte sería lo efímero, lo frágil, lo perecedero.

Al perfecto equilibrio que posee en sí misma como figura geométrica, se opone la idea de lo inasible y fugaz, sobre todo si es transparente y brillante. Hay que recordar una de las representaciones del Vanitas que muestra un amorcillo jugando con una mano a hacer burbujas transparentes que vuelan por el aire, mientras que con la otra sostiene firmemente una gran calavera. Por lo tanto, es sumamente interesante esta dicotomía de la esfera como lo inmutable y lo efímero.

\section{Universo $=$ Mundo, bóveda celeste.}

Se pueden asociar fácilmente a la idea del universo las cualidades de ingravidez y armonía, por lo que una esfera suspendida en el espacio nos remite a los astros generando su propio movimiento y equilibrio. El orden implícito en esta representación se rompe abruptamente si colocamos a la esfera o al circulo sobre una línea recta horizontals el equilibrio y la ingravidez se convierten en inestabilidad y falta de dirección. De tal manera que volvemos a encontrar dos conceptos polarizados según el contexto iconográfico en que se inserten: universalidad en el caso de ciertos valores esenciales como el conocimiento y la virtud, o contingencia, en el caso de la fortuna, los falsos valores y la inestabilidad de la vida humana.

\section{Tiempo $=$ Continuidad, devenir.}

La representación del tiempo como serpiente mordiéndose su propia cola, conlleva la idea de un movimiento continuo sin principio ni fin, esquematizada de manera óptima en el círculo. Saturno, el implacable Cronos que devora hasta ias piedras, es vencido tan solo por la Historia isi es que ella no ha de perecer también! Esta alegoría contiene una carga simbólica de gran belleza y expresividad.

Con lo visto hasta ahora podemos conjeturar que el círculo y la esfera son elementos pictóricos de gran riqueza en su efectividad visual y de alto contenido simbólico.

Algunos ejemplos en la pintura occidental

Una de las representaciones pictóricas más tempranas que incluyen esferas o espejos convexos en sus elementos iconográficos es, como lo 
anota Xavier Moyssén, ${ }^{\ddagger}$ el retrato de Los Esposos Arnolfini pintado por Jan Van Eyck en 1434. En esta obra, el espejo convexo colgado en la pared a espaldas y en medio de los esposos, refleja, distorsionándola, la parte posterior de la escena en la cámara nupcial oculta a los ojos del espectador.

Andrea del Castagno pinta un fresco hacia 1455 con las imágenes de Cristo y San Julián, en el cual Cristo sostiene con la mano izquierda una esfera dorada a la altura del pecho, llevando la mano diestra en actitud de bendecir. Una cruz formada con los pliegues de su túnica se posa sobre la esfera con lo que se puede apreciar el símbolo de la universalidad del Cristianismo sobre el mundo. Recordemos que el oro significa incorruptibilidad. El fresco se encuentra en la iglesia de la Annunziata de Florencia."

Existe un grabado alemán realizado en 1466 por el Maestro E. S., 1lamado La Virgen y el Niño de Einsiedeln, en el cual se ve una representa. ción tradicional de la madona con el niño y éste sostiene una esfera con la mano izquierda. ${ }^{5}$

En La Virgen y el Niño, óleo pintado por Carlo Crivelli en 1475, pintor veneciano, aparece la figura de la Virgen con el niño entre una profusión de follajes y de frutos; el niño sostiene con ambas manitas una fruta totalmente redonda.

Otra imagen que presenta una esfera en su estructura compositiva es la de Cristo Pantocrator en un fresco pintado en 1501 por Pedro Berruguete, en la iglesia parroquial de Guaza de Campos, España. Cristo, con un gran manto, levanta la mano derecha y con la izquierda sostiene una enorme esfera traslúcida, llena hasta la mitad de agua o líquido; una cruz descansa sobre ella. ${ }^{*}$

La Melancolía de Alberto Durero, grabado realizado en el año de 1514, presenta una gran esfera en reposo, a los pies de la pensativa figura, al lado de otros elementos simbólicos."

Siguiendo en estos ejemplos un orden cronológico, tenemos el óleo pintado en 1514 por el pintor flamenco Quintín Metsys, de la escuela de

‘Xavier Moyssén, "Montenegro,Pintor Contemporáneo" en Roberto Montenegyo (1885-

1968) Dibujos, grabados, óleos, pinturas munales, México, Academia de Attes, Museo de Arte Moderno, agosto-septiembre 1970, I.N.B.A., sin pág

"Las Bellas Artes. Enciclopedia ilustrada de pintura, dibujo y escultura, El Arte italiano basta 1850, tomo II, Nueva York, Ed Grolie1, 1969, p 204

¿ Las Bellas Artes, Enciclopedia ilustrada de pintura, dibujo y escultura, Arte Alemán y Español basta 1900, tomo IV, Nueva York, Ed Grolier, 1969, p 114

:El Arte Italiano, op cit, p 61

"Arte Alemán y Español, op cit., p. 165

"John Ruskin, "El arte del grabado. Durero y Turner" en México en el Arte, Nueva Época, Invierno de $1985 / 86$, IN B A S E P, no 11 , pp 77.79 
Amberes, intitulado El Prestamista y su Esposa. En esta escena de interiores, un próspero burgués examina minuciosamente una joya, sentado frente a su mesa de trabajo, mientras su mujer le asiste a su lado con un libro abierto. En la mesa hay varios objetos: monedas, joyas, cofrecillos abiertos y casi en el eje central, en diagonal con la mano del hombre que sostiene la joya, un espejo convexo en un marco redondo, formando parte del instrumental de trabajo, refleja un gran ventanal y la parte izquierda de la habitación que escapa a la vista del espectador. En un ambiente intimista característico de la escuela Flamenca, esta pintura capta la minuciosidad ritinaria de valuar una joyas, realizada por este hombre y su esposa El espejo, significativamente, se relaciona aquí con un oficio en el cual -al igual que el de pintor- la vista es primordial y en el que el brillo de las joyas y de la luz de la ventana se multiplica y prolifera en iridiscencias mágicas. También recuerda la vanidad y las riquezas del mundo. ${ }^{11}$

El autorretrato de Francesco Mazzola, conocido como el Parmigianino. realizado al óleo en 1527, es el ejemplo más acabado de un autorretrato inscrito en una esfera, mencionado como claro antecedente de los Montenegro por varios autores. ${ }^{11}$ Dentro de un espacio circular, en la parte superior del eje vertical central, aparece la cabeza del pintor casi sin deformación alguna, pero su mano derecha se aproxima en un violento escorzo que recuerda el motivo formal característico de los autorretratos de Montenegro. Del entorno se distingue la ventana deformada en la parte superior izquierda, elemento favorito en estos esquemas pictóricos. ${ }^{12}$

Nicholas Hilliard realiza un dibujo a pluma con lavado sobre lápiz, Retrato de la Reina Isabel, hacia 1584, en el que aparece la soberana en su trono portando un cetro en la mano derecha y el globo del orbi sostenido con la izquierda. ${ }^{13}$

San Francisco renunciando al Mundo es el tema pintado por Bartolomé Esteban Murilo en un óleo estructurado a base de motivos iconográficos llanos y evidentes: una enorme figura de Cristo en la Cruz se inclina hacia su lado derecho, desclavando una mano para acoger a San Francisco, quien, con un pie sobre una gran esfera, abraza vehemente al Crucificado, ${ }^{14}$

${ }^{10}$ Las Bellas Artes Enciclopedia ilustrada de pintura, escultura y dibujo, Arte Fla. menco y Holandés, tomo III, Nueva York, Ed. Grolier, 1969, p. 142

11 Véase: Justino Fernández, Roberto Montenegro, México, UN AM, 1962; Xaxier Moyssén, op cit, Olivier Debroise, Catálogo. Roberto Montenegro (1887-1968), Museo Regional de Guadalajara, CRO-INAH-SEP, junio-agosto 1984

12 El Arte Italiano, op. cit., p 117

${ }_{13}$ Las Bellas Artes. Enciclopedia ilustrada de pintura, dibujo y escultura, El Arte Inglés y Norteamericano basta 1900, tomo VI, Nueva York, Ed. Grolier, 1969, p 161

${ }^{14}$ Los Pintores Célebres, tomo II, Barcelona, Ed. Gustavo Gili, 1963, pp. 46.47 
Otra obra que presenta esferas en su iconografía es la escena de interiores pintada por Hendrick Terbrugghen en 1627, llamada Jacob reprendiendo a Labán. Pintor de la escuela de Utrecht, Terbrugghen asimiló la influencia de Caravaggio convirtiéndose de este modo, en precursosr de Jan Vermeer. El cuadro presenta a dos hombres discutiendo después de comer, en sobremesa, frente a una mujer, mientras otra se asoma curiosa por una puerta de la habitación. En medio de la mesa todavía con restos de comida, aparece un botelloncito de cristal transparente a medio llenar, de forma esférica perfecta. En la misma dirección hacia la parte superior, cuelga del techo un candil plateado cuyo centro es otra esfera que refleja, entre blancos destellos, la escena. ${ }^{15}$

Uno de los reyes godos pintados para el Palacio de Madrid, aparece sentado en su trono ataviado suntuosamente y coronada la cabeza, sostiene una gran espada con la mano derecha y una gran esfera o globo descansa sobre su pierna izquierda bajo la mano que se posa sobre ella. Este óleo de la escuela Sevillana fue pintado en 1643 por Alonso Cano. ${ }^{16}$

Santa Dorotea, pintada por Francisco de Zurbarán en 1650, lleva con ambas manos una charola llena de redondas frutas. ${ }^{17}$

Como dato curioso, una de las hilanderas del célebre cuadro de Velázquez, pintado en 1657 , sostiene con la mano derecha un ovillo redondo hecho del hilo con que realiza su labor.

Aubrey Beardsley, dibujante inglés quien influyó en los dibujos de Montenegro, recibió a su vez, influencia del pintor norteamericano James McNeill Whistler, sobre todo por la gran admiración que el inglés tenía por su cuadro intitulado La Estancia de los Pavo Reales. De Whistler es un retrato de Thomas Carlyle, realizado en 1872, en donde aparece el personaje sentado de perfil, frente a dos cuadros colgados en la pared, en uno de los cuales aparece un globo, seguramente un dibujo de algo redondo. A espaldas de Carlyle se ve su monograma inscrito en un círculo. En otro óleo, The Lange Lijzen of the Six Marks, una mujer sentada sostiene un jarrón chino, a su espalda hay una repisa de chimenea sobre la que se ven chinerías, un gran plato recargado en la pared recuerda los espejos redondos de los que hablamos. ${ }^{18}$

No hay que pasar por alto la obra del grabador holandés Maurits Cornelis Escher, quien en 1934 y 1935 publica unas litografías llamadas Naturaleza Muerta reflejada en un globo y Mano con esfera reflejante, esta

${ }^{15}$ Arte Flamenco y Holandés, op. cit, p. 163.

16 Arte Alemán y Español, op. cit, p. 169.

17 Ibidem, p. 214

${ }^{18}$ Las Bellas Artes. Enciclopedia ilustrada de piniura, dibujo y escultura, Impresionistas y Postimpresionistas, tomo VII, Nueva York, Ed. Grolier, 1969, p. 122. 
última un autorretrato del artista. En 1946 se repite este tema en el trabajo intitulado Tres Esferas. ${ }^{19}$

Por último es conveniente señalar la muy probable influencia de la perspectiva llamada curvilinea tratada por el arquitecto y pintor Luis G. Serrano en 1934 en su libro Una nueva perspectiva, la perspectiva curvilinea. Este nuevo concepto picto-gráfico es evidente en los autorretratos de Montenegro. ${ }^{20}$

\section{La obra: una posible clasificación}

Esta primera clasificación se ha llevado a cabo en un número aproximado de 165 obras, de las que se han estudiado físicamente 75 originales y el resto en diapositivas y reproducciones. Los incisos o apartados resultantes son:

1. Personajes sosteniendo una esfera o al lado de ella.

a) Alegoría de la Muerte (Tinta, 1909).

En este dibujo enmarcado en el espíritu decadentista finisecular, Montenegro evoca a la Muerte como un gran esqueleto coronado, de pie frente a una barda sobre la que se ve un frutero con flores y frutas; en el lado opuesto, a espaldas de la Muerte, una columna con reminiscencias jónicas y más al fondo las ruinas de un brumoso castillo, recuerdan lo perecedero de los bienes de la vida. El esqueleto viste suntuosa vestimenta real; en la mano derecha sostiene una guadaña vuelta hacia abajo, mientras que en la izquierda, porta una gran esfera brillante. Figura 5 (Colección INBA-SEP).

b) Retrato de Hoyningen-Huene (Óleo sobre tela, 1940).

El retratado, que es fotógrafo, sostiene una esfera con la mano izquierda y recargándola sobre el antebrazo derecho, refleja vivamente la habitación con su gran ventanal y el caballete del pintor.

c) Hecatombre (Óleo sobre tela).

La concepción formal de este cuadro se basa en volúmenes anatómicos disgregados y figudas geométricas rotas en pedazos. En el centro de la composición, una gran mano sostiene una enorme esfera sobre la cual caen gotas de sangre. En un plano posterior, la figura de un niño pequeño sin cabeza sostiene una esfera transparente. Tanto la mano como el niño tienen apariencia pétrea, como de escultura rota.

19 Xavier Moyssén, op. cit., sin pág.

${ }^{20}$ Ibiden. 
d) Retrato de Jesús Reyes Ferreina (Óleo sobre tela, 1930).

El pintor aparece sentado, de tres cuartos, con la mano izquierda sostiene un relicario con el retrato de una mujer. Frente a él aparecen varios nbjetos, de izquierda a derecha: una botella, un plato, una imagen religiosa y una gran esfera que refleja el estudio donde se encuentran. Se ve en este reflejo a Montenegro entregado a la tarea de retratar a Reyes Ferreira.

e) El Ärbol de la Vida. Ex-iglesia de San Pedro y San Pablo (Mural).

En el extremo izquierdo, la primera figura femenina de las doce que componen el conjunto, porta una esfera entre las manos. Este es el primer mural pintado por Montenegro dentro de la gestión vasconcelista.

f) Murales en el despacho de Vasconcelos. Secretaría de Educación Pública.

En uno de estos murales, cerca del retrato de Gabriela Mistral, una figura femenina sentada de perfil, alarga las manos con una esfera en actitud de ofrenda. En otro mural llamado La Sabiduría, se ve el símbolo chino T'ai Shi, consistente en un círculo dividido por una línea curva: la parte blanca simboliza la luz, el cielo y lo masculino (el yang); mientras que la parte negra es la noche, la tierra y lo femenino (el yin). En ambos murales, círculos concéntricos remiten a la idea del cosmos o el universo.

g) Iberoamérica. Biblioteca Iberoamericana (Mural).

Hay dos grupos de personajes retratados en este gran mural: en la figura central de la composición de la izquierda, Cristóbal Colón, se ve un gran globo transparente que lo sujeta con ambas manos.

\section{Personajes sosteniendo una esfera opaca.}

a) Fantasia hegeliana (Aguafuerte).

Una mujer de rasgos refinados y sonrisa misteriosa, se lleva la mano izquierda a la cintura mientras que con la derecha sostiene una esfera, delicadamente, entre los dedos.

b) La Marquesa de Cassatti Stampa (Dos versiones: Tinta 1914 y óleo/tela 1917).

En ambas, la figura de la marquesa sostiene un elemento esférico en la palma de la mano izquierda. En el dibujo a tinta parece un botelloncito.

c) El hombre de la camisa rosa (Óleo/tela).

El retratado, un hombre joven, sostiene con la mano izquierda una esfera opaca y se lleva la otra a la cintura. Figura 6.

d) Retrato de Rugena (Óleo/tabla 1917). 
DOI: http://dx.doi.org/10.22201/iie.18703062e.1986.57.1329

IV.

PRINCIPIUM.

Procreat ex rihilo terre totum Deus orbem

Sydera, ture hominem, monftra marina et aquas.

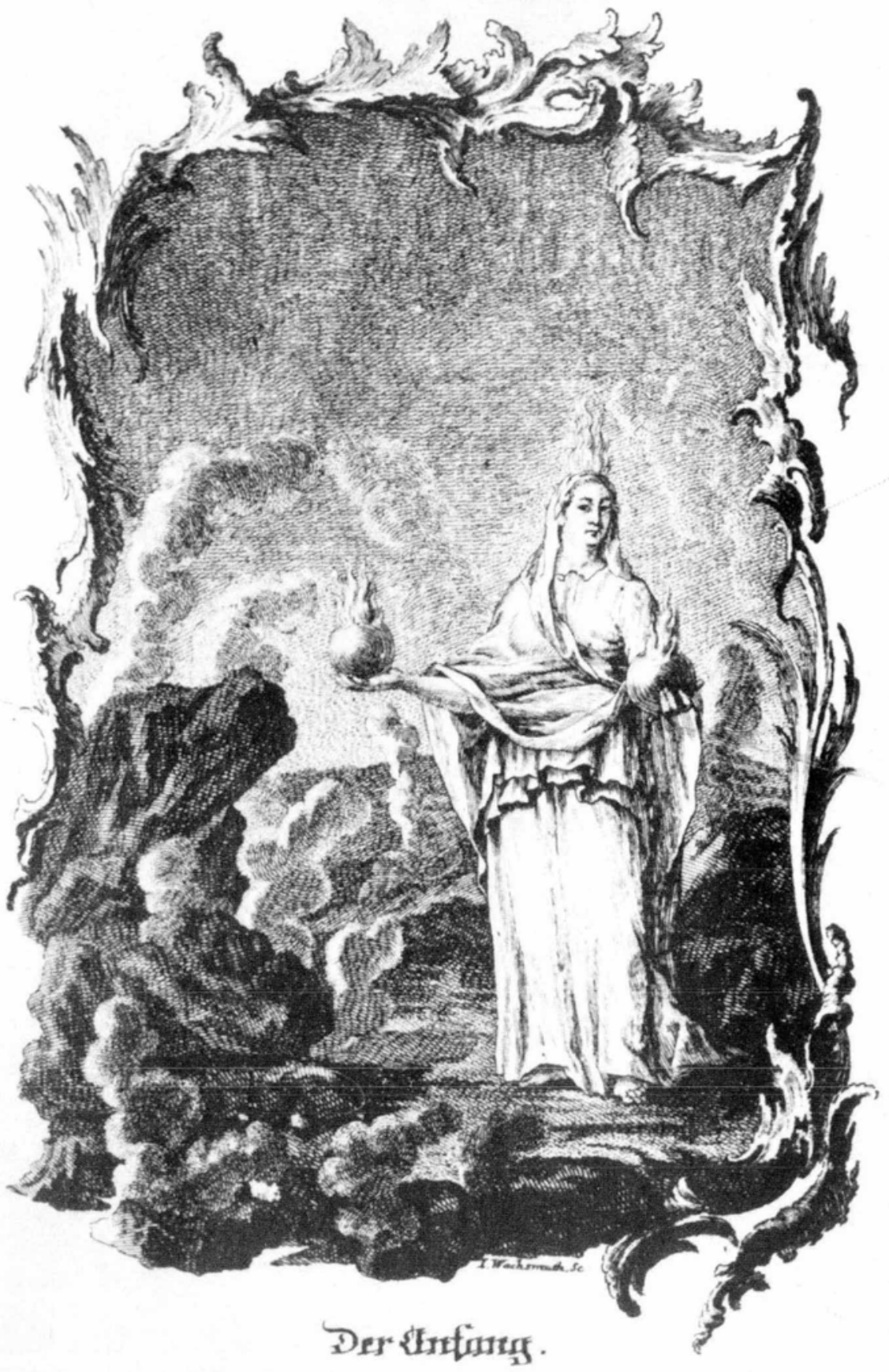

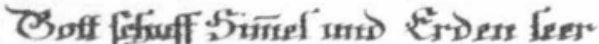

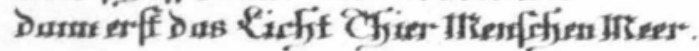

Fichler del.

Hertal areud

Figura 1. Césare Ripa, Principium. 
DOI: http://dx.doi.org/10.22201/iie.18703062e.1986.57.1329

LXXXVI

SUBMISSA MENS .

86

Inquinet egregios ne ftulta Supetria mores

Semel propofuit nobis Coristis farmulatus

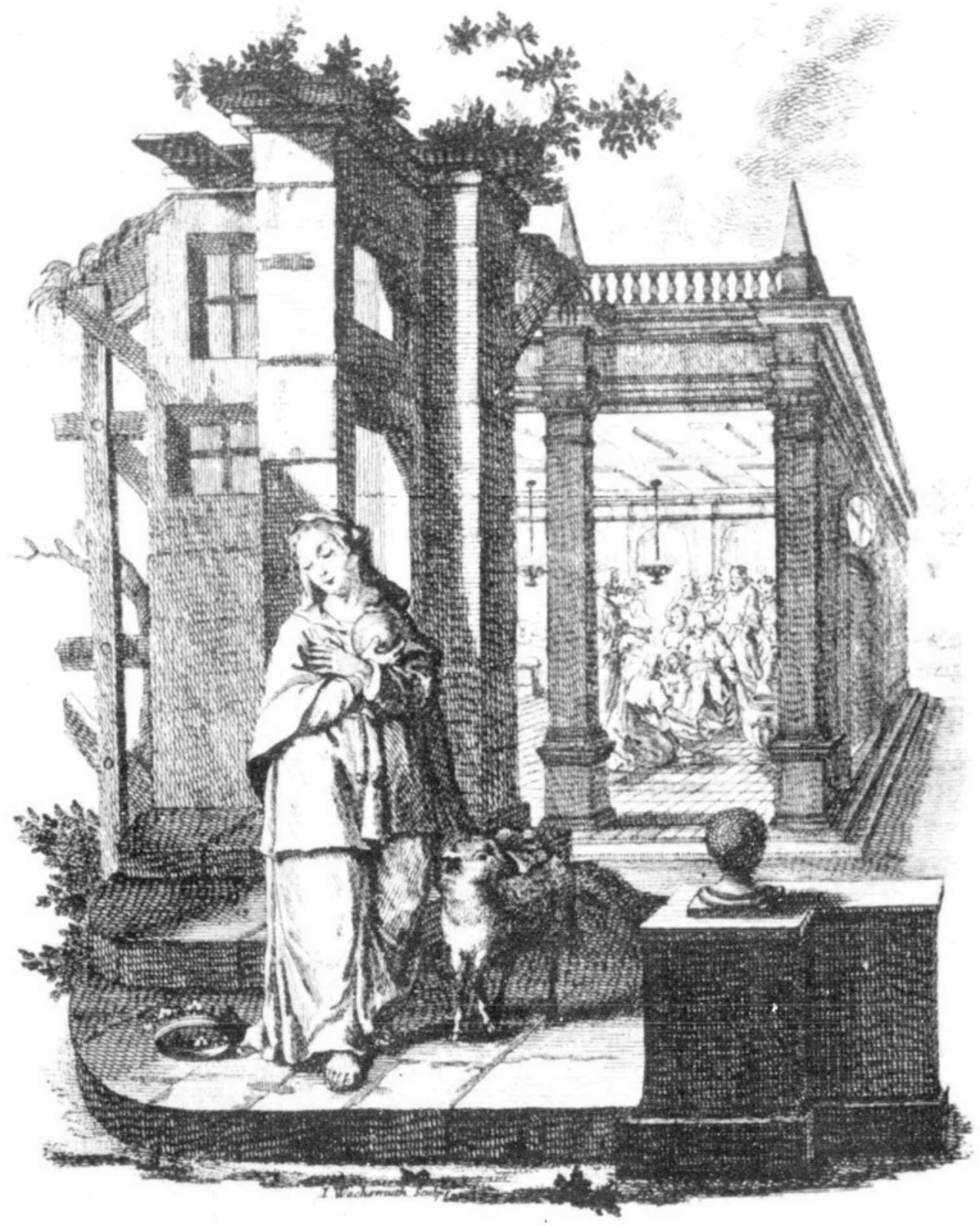

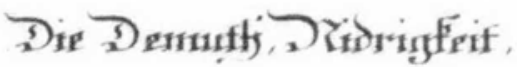

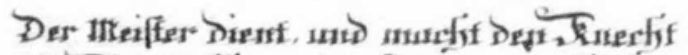

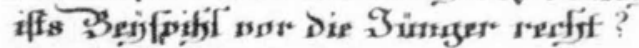

Figura 2. Césare, Ripa, Submissa mens. 
DOI: http://dx.doi.org/10.22201/iie.18703062e.1986.57.1329

CI.XXXVII. SCIEN'TIA

188.

Aegypti rex Ptolomaeus multum ad frudiorzan autiom. que inereinentum contulit; Namque epus opera factum git. ut aliorum foritu colligerentur, a bibliothea conftitucretur

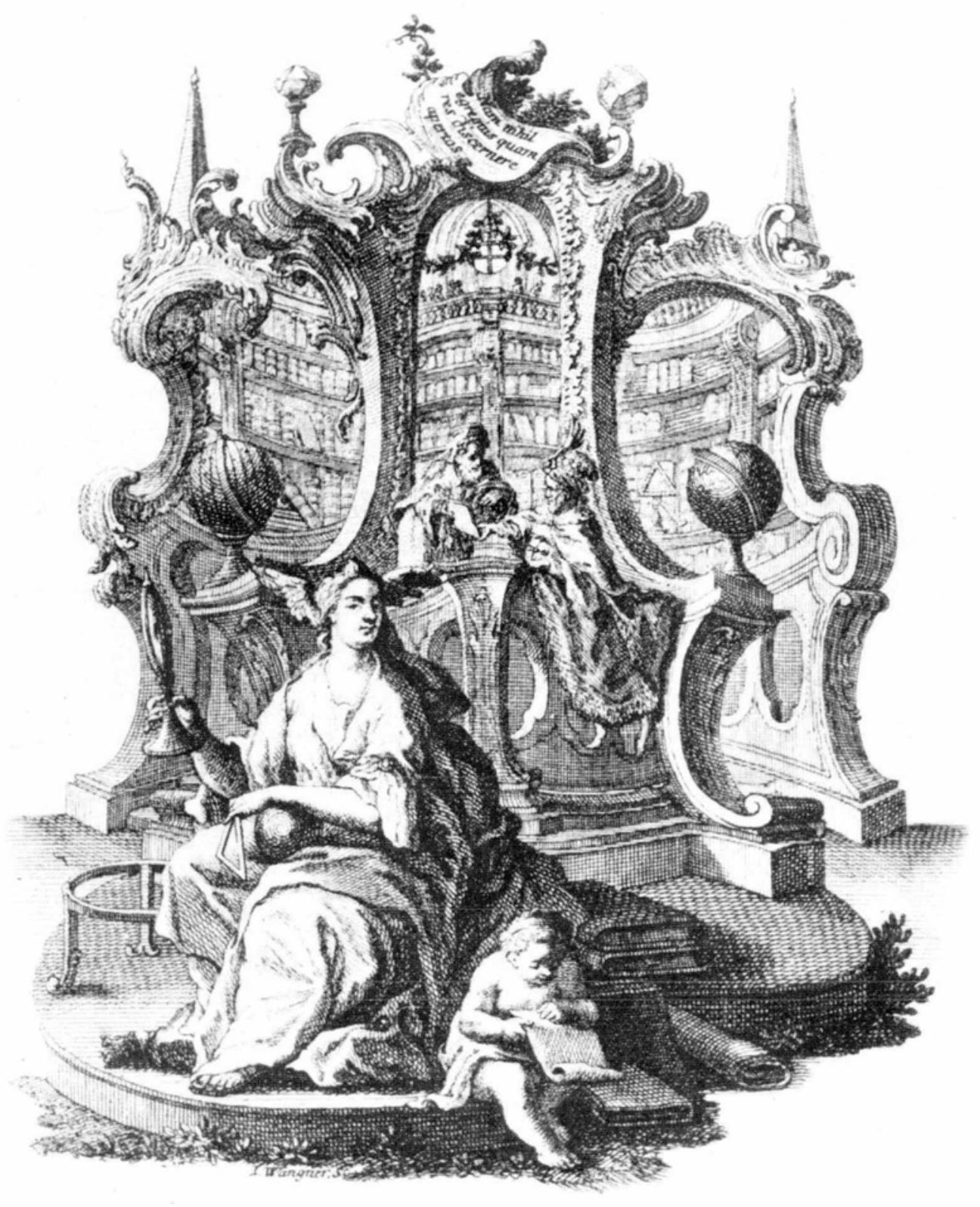

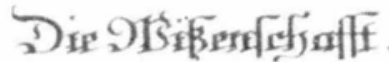

Dre. Pा

brurfif Ptolomeus fionfi entop?

Figura 3. Césare, Scientia. 
DOI: http://dx.doi.org/10.22201/iie.18703062e.1986.57.1329

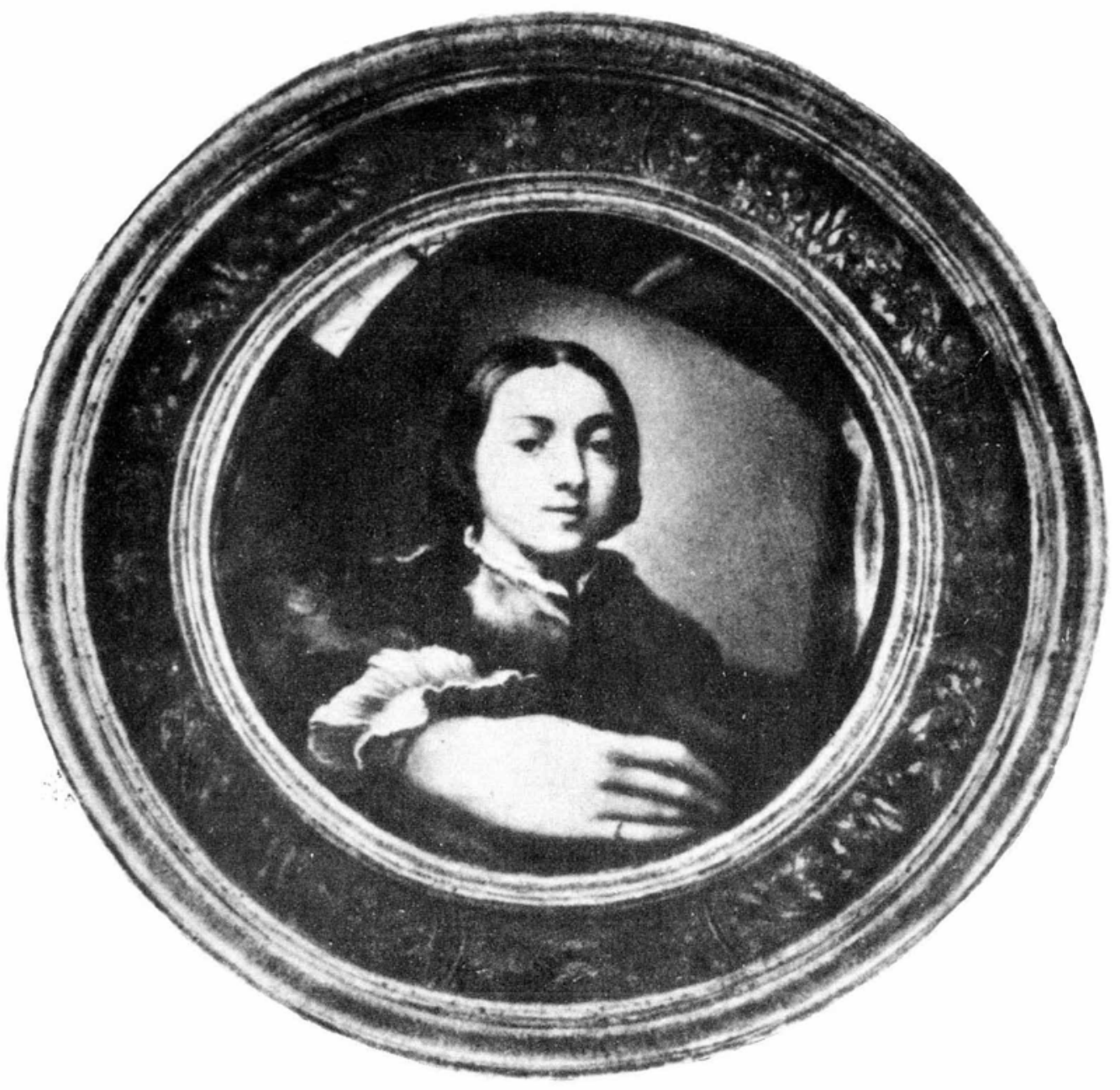

Figura 4. Francesco Mazzola, el Parmigianino, Autorretrato, 1527. 


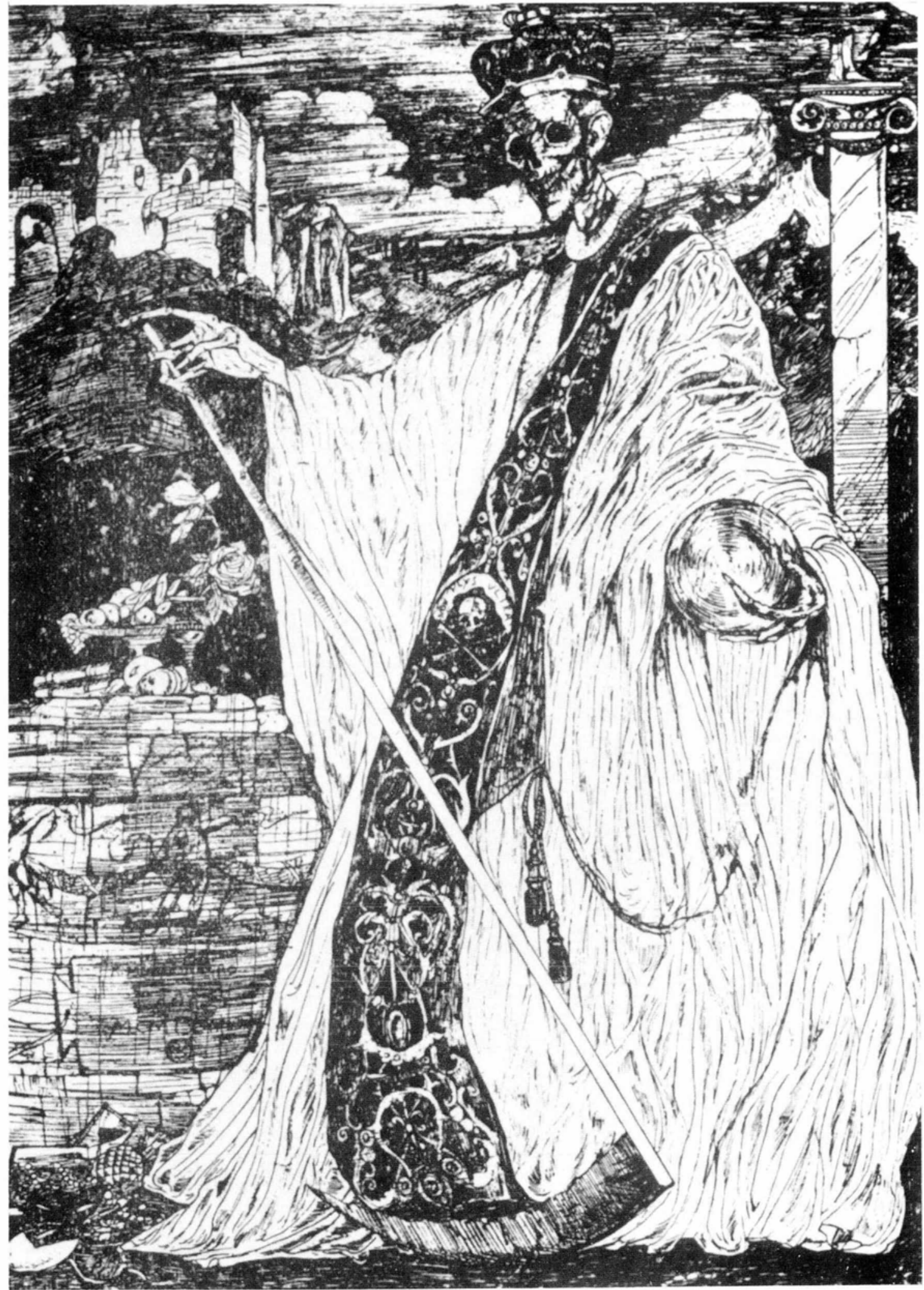

Figura 5. Roberto Montenegro, Alegoría de la Muerte, Tinta, 1909. 


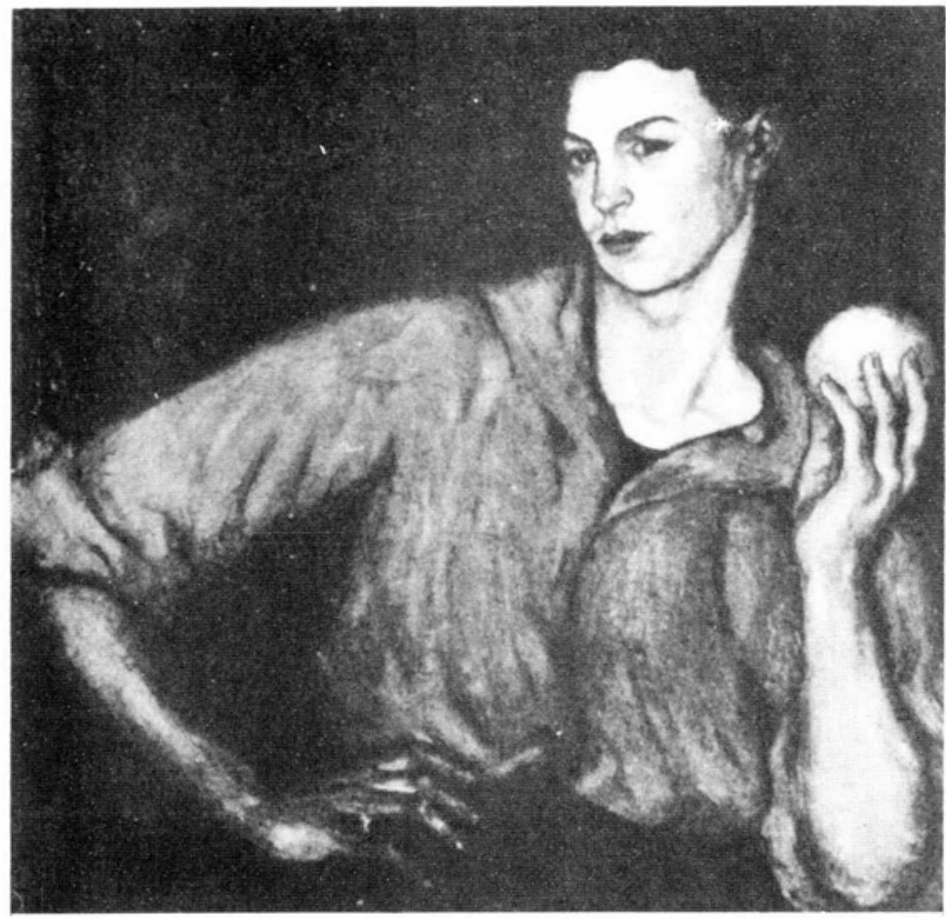

Figura 6. Roberto Montenegro, El hombre de la camisa rosa, sin fecha.

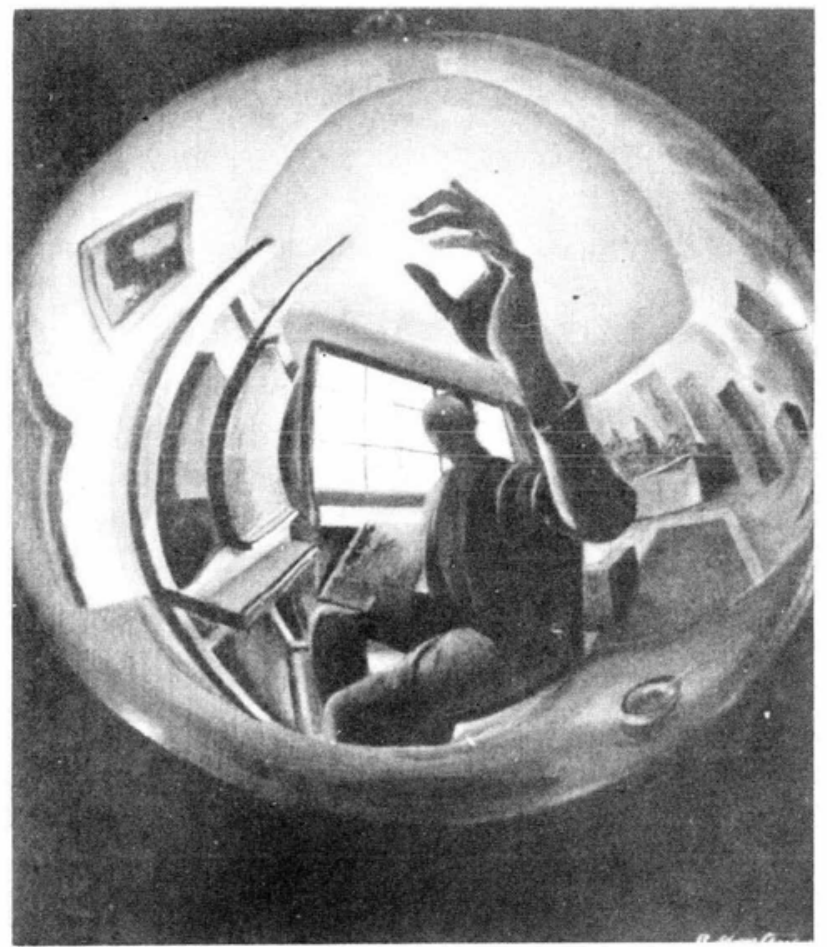

Figura 7. Roberto Montenegro, Autorretrato, 1941. 
DOI: http://dx.doi.org/1022201/iie_18703062e_1986.57.1329

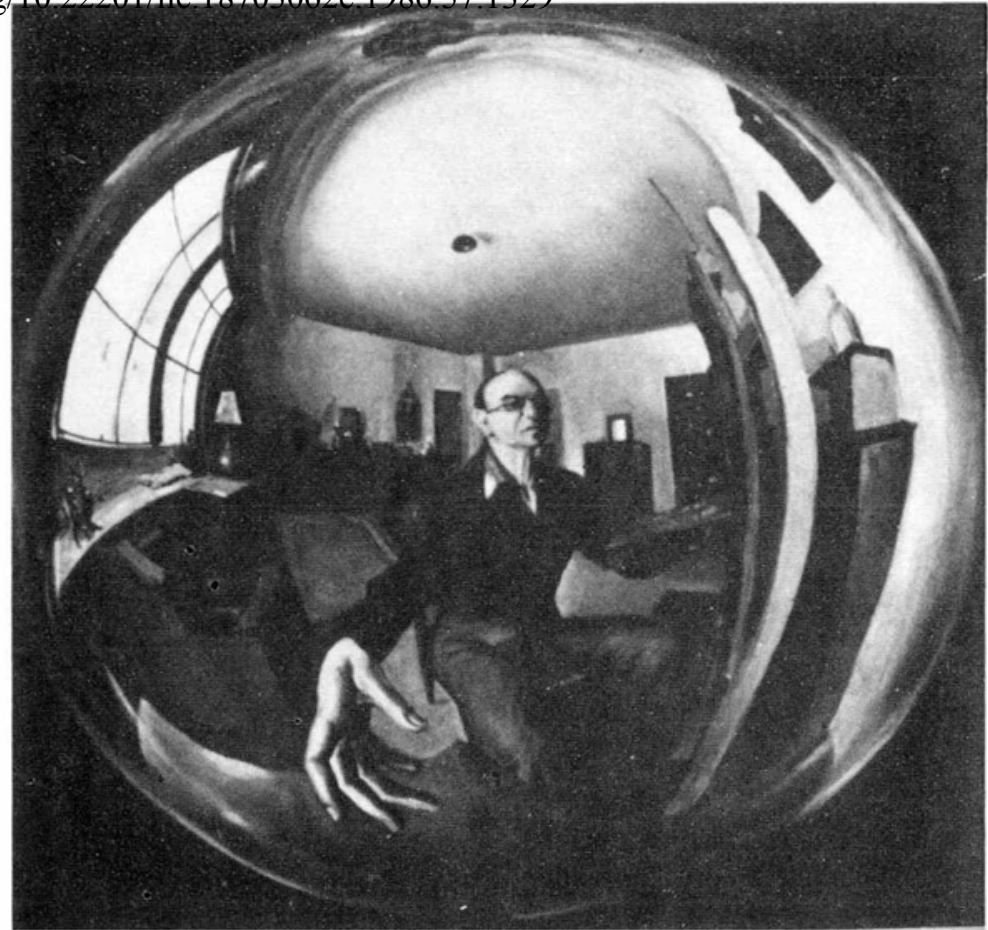

Figura 8. Roberto Montenegro, Autorretrato, 1942.

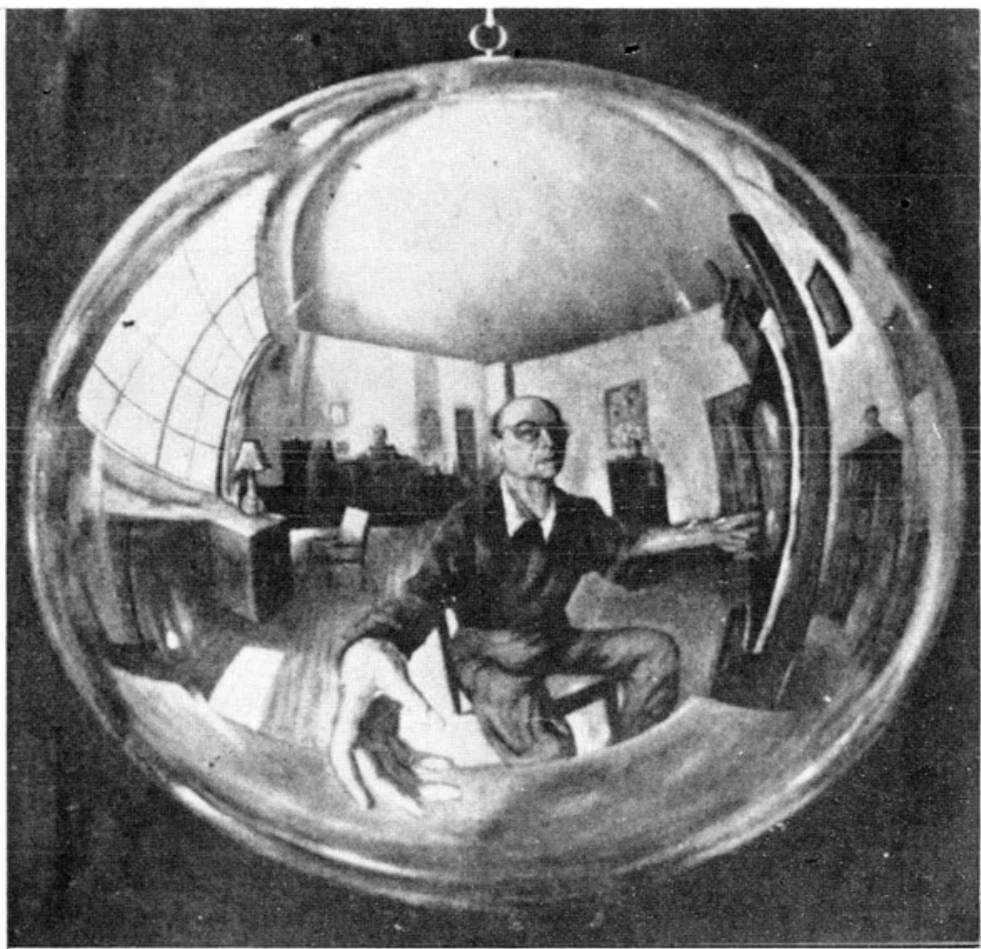

Figura 9. Roberto Montenegro, Autorretrato, sin fecha. 


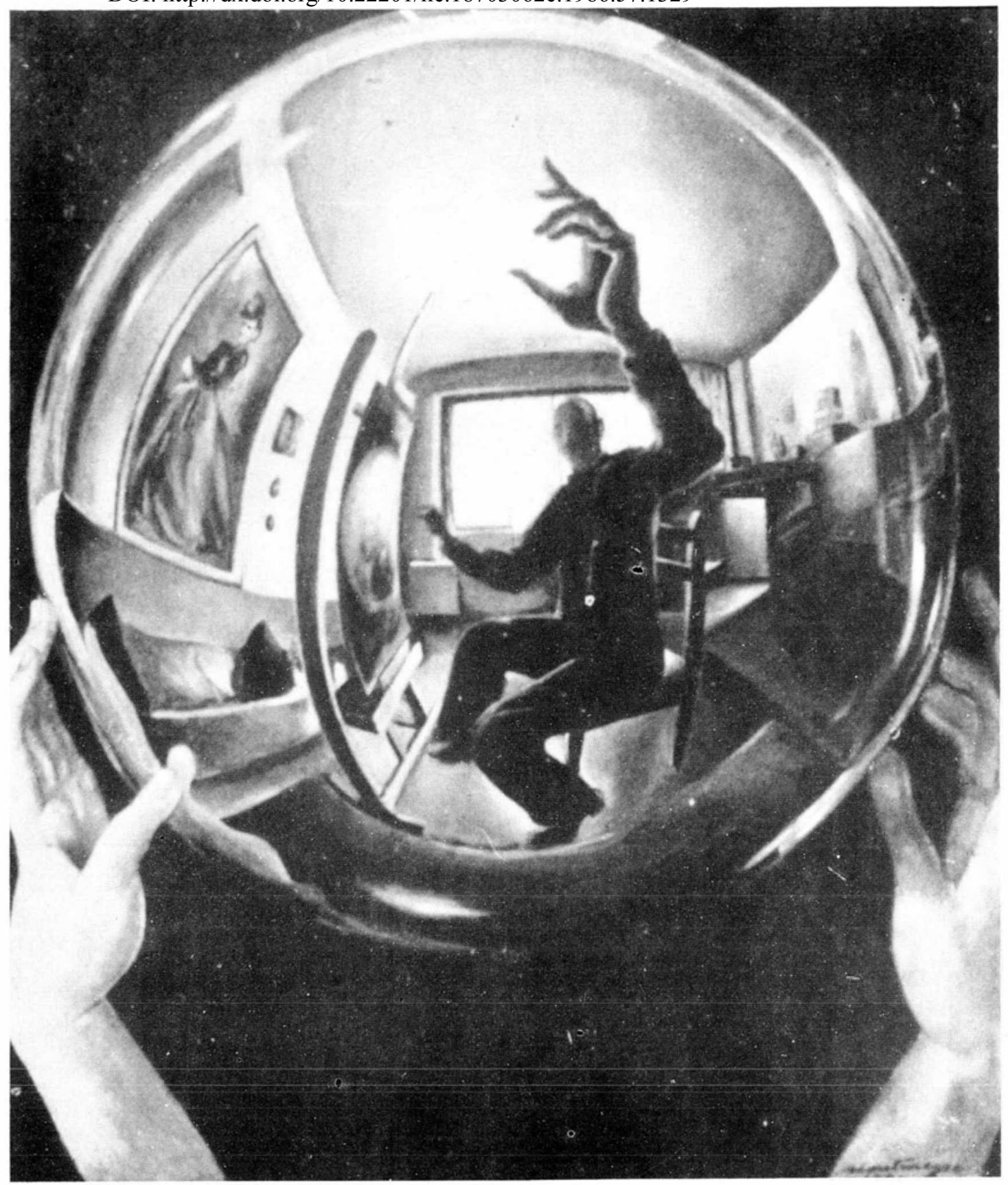

Figura 10. Roberto Montenegro, Autorretrato, 1946. 


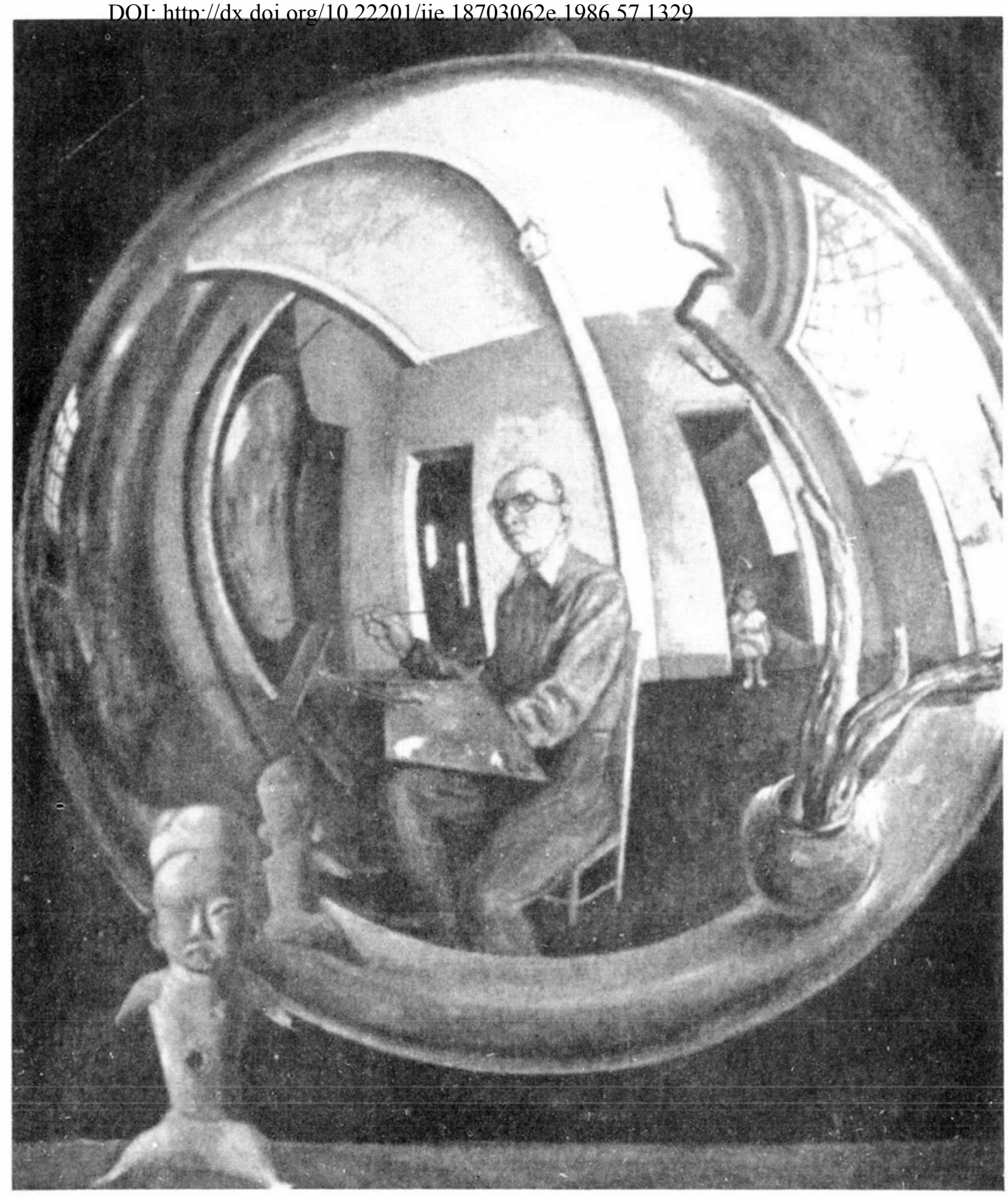

Figura 11. Roberto Montenegro, Autorretrato, 1954. 


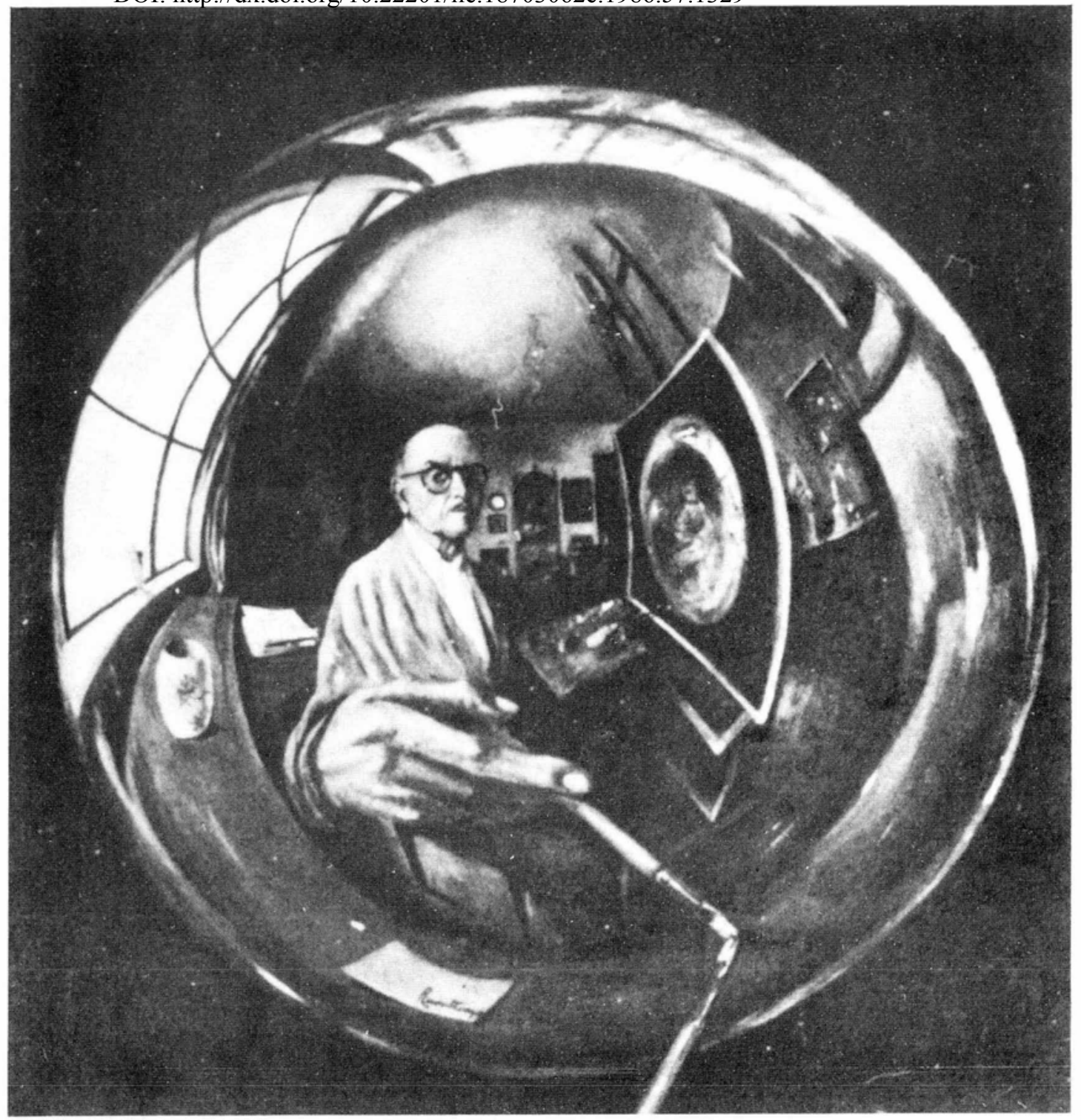

Figura 12. Roberto Montenegro, Autorretrato, 1955. 


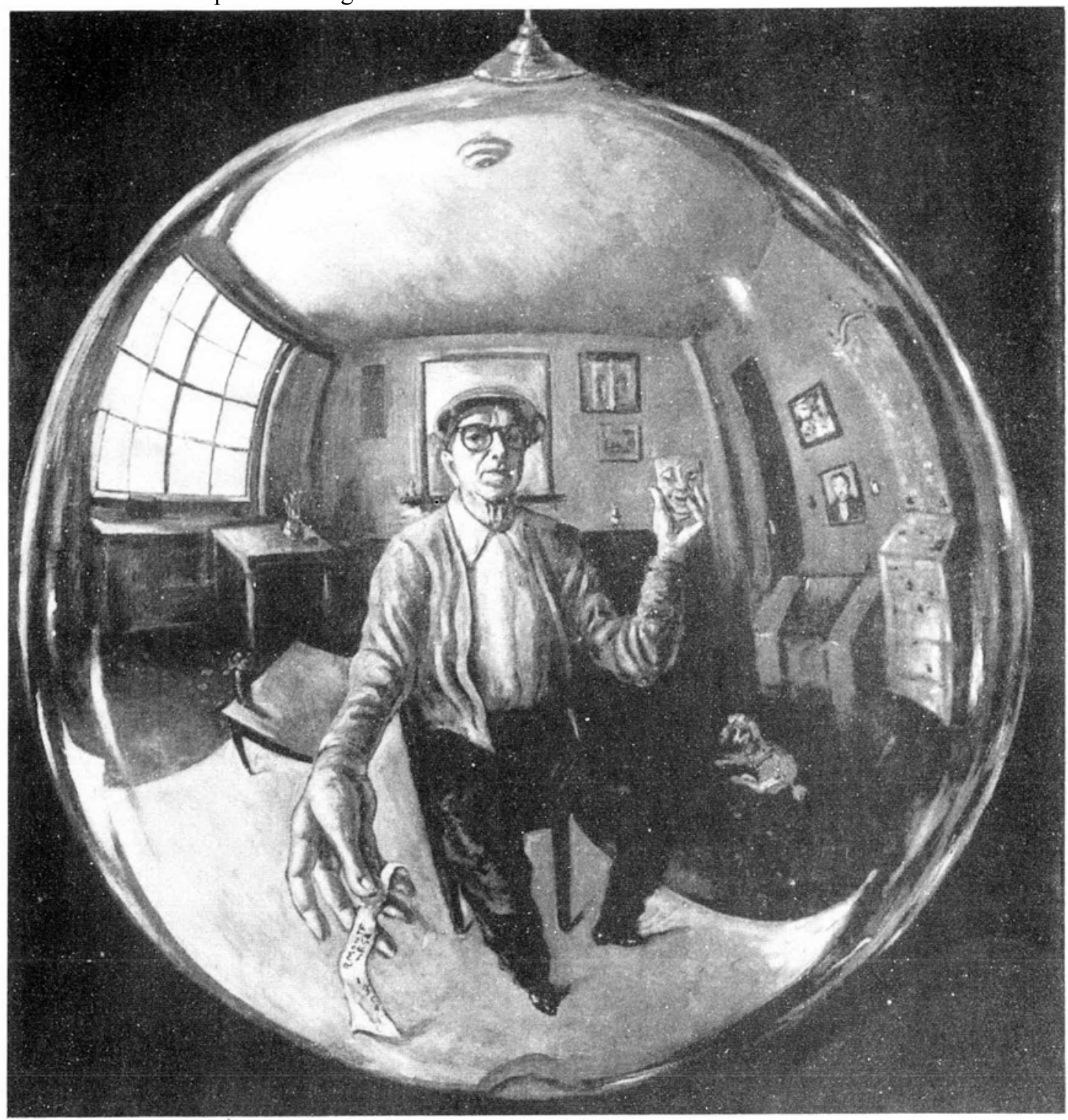

Figura 13. Roberto Montenegro, Autorretrato, 1959. 


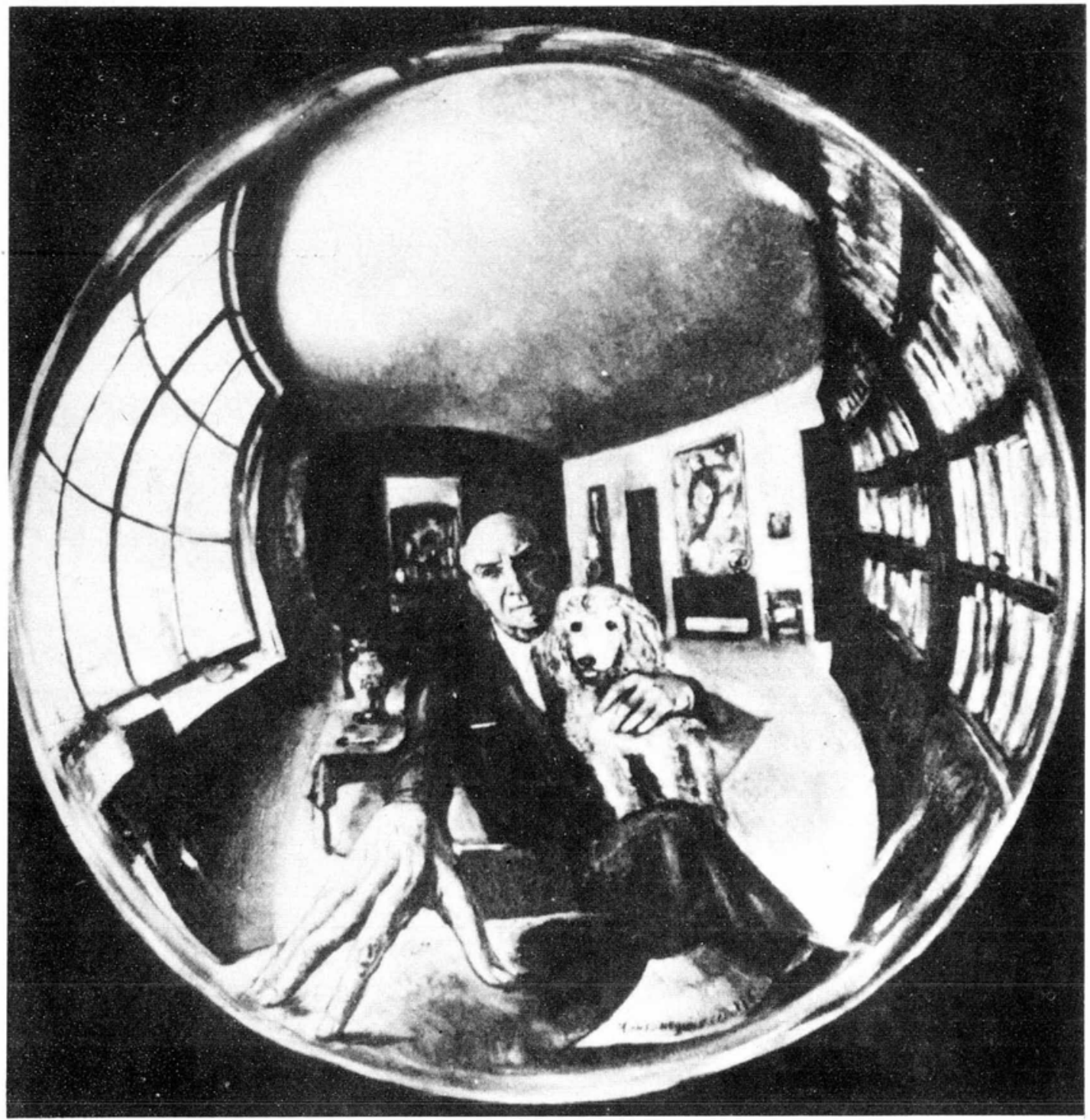

Figura 14. Roberto Montenegro, Autorretrato, 1961. 
Un retrato tradicional de tres cuartos de esta mujer evocada por Montenegro con emoción; en la mano izquierda que descansa sobre una mesa, se ve una esfera opaca.

e) La niña de la manzana (1950).

Una pequeña lleva un frutero con frutas redondas.

f) Tianguis (Grabado, 1919).

Una mujer indígena alarga la mano con una fruta para dársela a un hombre ensarapado sentado en el suelo. Figuras de un mexicanismo pletórico de exotismo.

g) Tres mujeres con niño (Tinta, 1948).

Una de las mujeres sostiene en la mano una fruta o un objeto redondo.

h) El Jarabe Tapatío (Vitral, 1922).

La figura masculina en el extremo derecho del vitral, en traje de manta blanca, descansa la barba sobre la palma de la mano mientras observa bailar el tradicional baile. En esa misma mano lleva una fruta o esfera de color ocre.

\section{Lineamientos surrealistas.}

a) El hijo pródigo (Óleo sobre tela, 1946).

En la sección media inferior, aparece una esfera flotando junto con elementos surrealistas tales como un gran torso esculpido a la manera clásica y unas máscaras que evocan la dramaturgia griega. La esfera es azul y se interpone entre la figura del hijo que retorna, desplazándose desde la parte inferior izquierda, y la madre que espera, estática, en el umbral de su casa.

b) ¿Es cultura? (Óleo sobre tela, 1943),

Un enorme ensamblaje compuesto por referencias volumétricas, evoca una escultura femenina fragmentada y se burla, con ironía, de ciertos conceptos del arte y la cultura modernos. En la base de la "escultura" están colocadas tres esferas: una en el extremo izquierdo y las otras dos en el derecho, formando con otros elementos, el plano donde se asienta la composición principal, pletórica de sugerencias oníricas.

\section{Lineamientos mexicanistas.}

a) Tehuana y su muerto (Óleo sobre masonite).

Una mujer indígena vela a un cuerpo rígido tendido a lo ancho del espacio pictórico; tiene el rostro vuelto hacia el lado contrario del muerto, con una expresión de coraje y dureza. En la parte superior izquierda 
se ve un gran globo -esquematizando un globo terráqueo- sostenido por una base.

\section{Autorretratos.}

Estos autorretratos ${ }^{21}$ presentan un esquema formal y conceptual similar, salvo algunas variaciones mínimas que se pueden apreciar de un cuadro a otro. Se trata básicamente, de un espacio tridimensional esférico dentro del cual se retrata el pintor y su mundo: en el centro aparece Montenegro, en su estudio de pintor, rodeado de libros, pinceles y objetos íntimos; a veces un perro le acompaña y un gran ventanal ilumina la estancia. En ocasiones la esfera está sostenida por un hilo que pende de la parte superior oculta a nuestra mirada; en otra versión se encuentra sostenida por dos manos; y también la encontramos sin soporte alguno, como una esfera totalmente ingrávida en el espacio pictórico.

1941: En este autorretrato - desde mi punto de vista, uno de los más logrados - Montenegro esquematiza la figura suprimiendo todo trazo superfluo y concentrándose en aquellas formas que considera esenciales. La ausencia de rasgos faciales definidos hace pensar un poco en los maniquies de De Chirico, tal vez aludiendo a una paulatina "despersonización" del ser humano, el cual empezaba a verse inmerso en un incipiente culto por la máquina y la tecnología. Hay que recordar que ya desde el gobierno de Plutarco Elías Calles hubo un entusiasmo desbordado por la "técnica", la que se creía destinada a solucionar los problemas del país. En los años cuarentas, este fenómeno se acentúa con el inicio de la industrialización de la planta productiva, en un proceso que habría de transformar las estructuras sociales de México. Figura 7.

1942: Trabajando en su estudio frente a su caballete, Montenegro adelanta la mano derecha que sé deforma, por el espacio esférico, en violento escorzo. Por la posición del caballete no se aprecia lo que está pintando. Dentro de una afortunada estructuración de elementos visuales, este auto. rretrato es, tal vez, el más conocido. Figura 8.

Sin fecha: Trabajando frente a un lienzo que a su vez reproduce la esfera del autorretrato, Montenegro aproxima hacia el espectador la mano derecha. Por marcadas similitudes con el trabajo de 1942, ubico éste en una etapa cercana. Figura 9.

1946: Aquí vuelve a aparecer la figura sintetizada, sin los rasgos faciales del pintor. El conjunto, englobado en la esfera, está sostenido por dos manos. Figura 10.

21 Xavier Moyssén consigna seis autortetratos inscritos en esferas "de cristal azogado", en el periodo que va de 1941 a 1961. Op. cit., sin pág. Yo he registrado ocho. 
1954: En esta composición, Montenegro no adelanta la mano sino que se le ve trabajando con un pincel, frente a la tela de su caballete. Una niña pequeña se asoma por la puerta del estudio; en el lienzo está pintando la esfera con su autorretrato. En un primer plano y excluida del conjunto esférico, una figurilla prehispánica reposa sobre un estante. El conjunto pende de un hilo. Figura 11.

1955: En este interesante trabajo, Montenegro se refleja en un juego infinito de desdoblamientos y referencias: se ve al pintor frente al caballete reflejado en una gran esfera; sobre el lienzo que trabaja aparece la esfera que está pintando; la mano derecha se aproxima con el pincel hasta tocar la superficie de la esfera por lo que se duplica y es, de hecho, el único elemento visual perteneciente al "mundo real", ya que lo demás es tan sólo un reflejo. Figura 12.

1959: Sentado de frente y sin su caballete, Montenegro se retrata a si mismo sosteniendo en la mano izquierda una figurilla prehispánica y en la derecha una cartela con la fecha y su firma. Figura 13.

1961. En el último trabajo de esta serie, el pintor aparece en la parte media de la esfera abrazando a su perro y alargando la mano derecha que se deforma y se posa sobre una mesa en un primer plano, donde está un papel con su nombre; lo rodean un amplio ventanal y estantes colmados de libros. Figura 14.

Estos autorretratos sugieren a Justino Fernández el poema de Parménides: "Estas cosas así fueron y así son; pero, inmediatamente, de lo que son partiendo, y a madurez llegadas, tocará perecer a las presentes ..." ${ }^{22}$ Dentro de estas concepciones pictóricas, Montenegro se aisla del mundo exterior al encerrarse en un círculo perfecto donde no hay cabida para intromisión alguna - ital vez nostalgia por la protección y tibieza del vientre materno, como lo señala Xavier Moyssén?--, manifestando en todo caso un egocentrismo pictórico que no admite desequilibrio y en el que evidencia la importancia del trabajo artístico en esa mano derecha que pinta y se aproxima haciéndose descomunal. ${ }^{23}$

En el límite de este mundo esférico y hermético, encontramos también la fragilidad de la vida, el eterno devenir, el continuo movimiento y el equilibrio perfecto, el universo privado del artista y su redonda soledad. A la vez, puede apreciarse un irónico y fino juego en la cadena infinita de reflejos que se establece en alguno de los autorretratos: ¿cuál de estos

\footnotetext{
22 Justino Fernández, op cit, p. 31 .

23 Justino Fernández sugiere que esa "enorme mano. . tal vez es un símbolo del podet cteador". Ibidem, p. 27
} 
reflejos es la "realidad objetiva"? ¿Cuál de ellos es el verdadero retrato del pintor?

Existen otros trabajos pictóricos de Montenegro en los que emplea el círculo y la esfera como elementos puramente decorativos, y por lo mismc. carecen de connotaciones simbólicas de cualquier índole. Asimismo no hay que olvidar la influencia que pudieron haber tenido en la concepción pic. tórica de estos esquemas, las enormes esferas de colores brillantes propias de las manifestaciones del arte popular, del que Montenegro era un entusiasta apologista.

\section{Consideraciones finales}

Tal como lo señala Bialostocky, ${ }^{21}$ parecen existir elementos constantes en el empleo de motivos iconográficos de base en la representación pictórica, a lo largo de la historia del arte. Esto significa que los hombres tienden a utilizar en ocasiones, esquemas iconográficos existentes que hayan demostrado su efectividad visual, al ser dotados de cargas simbólicas acumuladas y enriquecidas durante su evolución histórica.

En la selección de la obra de Montenegro presentada en este análisis, se puede apreciar en el empleo de la esfera, un sentido cosmogónico primordial, del que derivan ciertos significados específicos según el contexto de la obra.

Desde los trabajos tempranos - dibujos a tinta y grabados, principalmente-, aparece la esfera relacionada con la muerte, de manera muy obvia, como en el ejemplo fechado en 1909, que ilustra este trabajo. Esta inquietud que le suscita la inexorable destrucción del universo del hombre, así como del ser humano mismo, se presenta reiteradamente en varios momentos de su obra, muy marcadamente en la etapa pre-europea, cuando la afinidad con el decadentismo finisecular $-\mathrm{y}$ su fascinación por lo perecedero- es evidente.

Durante su formación europea, Montenegro incursiona brevemente en las propuestas de las vanguardias, realizando algunas composiciones "cezannianas" o cubistas en las que los elementos geométricos cobran gran relevancia. En ellas aparecen esferas aquí y allá, dentro del planteamiento plástico de tales movimientos, pero sin alcanzar fuerza expresiva alguna.

Continúa con el empleo generoso de las decoraciones fitomorfas en las cuales desborda una profusión de frutas redondas, como es el caso de la realizada en el plafón del Antiguo Círculo Mallorquín, hoy Parlamento de las Islas Baleares, en Palma de Mallorca, España. Aquí se pueden apre-

${ }^{21}$ Jan Bialostocky, Estilo e Iconografía, Contribución a una Ciencia de las Artes, Barcelona, Ed. Barral, 1973, passim 
ciar remanentes de algunos grabados y viñetas de la época de la Revista Moderna, a base de festones y guirnaldas de flores y frutos, como los llamados Renacimiento, Tinta, 1908, y Fons Vitae, Tinta, 1909..$^{2.7}$ Estos motivos decorativos remiten asimismo, a los conceptos pictórico-ornamentales tratados por Serlio en su Tercero y Cuarto Libro de Arquitectura, lo que evidencia la formación académica de Montenegro.".

Ya de regreso en México y dentro de un "-manierismo en el siglo veinte", ${ }^{2 \pi}$ las propuestas plásticas de Roberto Montenegro se insertan, desde 1921, en una instancia histórica que requería de nacionalismos autoafirmativos, dentro de un programa cultural vasto y ambicioso estructurado desde la SEP por José Vasconcelos. En estas circunstancias, los murales de Montenegro retomarán en ocasiones, motivos iconográficos de sus etapas anteriores, ahora contextualizados en el nuevo orden social.

Cuando inicia su labor como pintor mural, Montenegro - como buen ateneísta - comparte el entusiasmo por la acción redentora de la cultura, subrayando la importancia del conocimiento y de la ciencia, por medio de alusiones simbólicas en los sucesivos trabajos que realizara. El primer mural que pinta, El Árbol de la Vida, llamado tambiên El Árbol de la Ciencia, es una exaltación humanística de los logros culturales del hombre y de la importancia de éste dentro de la cosmovisión modernista. Hay una gran figura masculina dotada de armadura medieval, colocada axialmente con el árbol frondoso de la vida; a sus lados, las figuras femeninas que lo accmpañan, portan diversos objetos y atributos: una de ellas, ataviada con túnica, la cabeza inclinada y la actitud que recuerda la submissa mens de Ripa, sostiene una esfera en las manos. Tanto en este mural como en el realizado para el despacho de Vasconcelos, en el cual Montenegro pinta a Gabriela Mistral, la alusión a la ciencia y al conocimiento parece clara e incuestionable. Aquí, la maestra y poetisa aparece entre una tupida enramada con flores blancas, que podrían simbolizar la pureza y la espiritualidad; bajo una lechuza conocida como emblema de la sabiduría; a su lado derecho, una joven vestida con túnica, sostiene entre sus manos una esfera.

Frente a este mural se encuentra otro, el cual ha recibido dos nombres: Rito Budista y La Sabiduría. En un punto de importancia visual -el eje central superior- Montenegro pinta el símbolo chino de la polaridad, considerado como de buena fortuna por las filosofías orientales. Este sím-

25 Roberto Monienegro (1885-1968) Dibujos, Grabados, Oleos, Pinturas murales, México, Academia de Artes, I N.B.A., 1970, ilustraciones 7 y 8 , sin pág

26 Sebastián Serlio Boloñés, Tercero y Cuarto Libro de Arquitectura, con una introducción por Víctor Manuel Villegas, Universidad Autónoma del Estado de México, 1978, passim.

${ }^{27}$ Oltvier Debtoise, op cit., p. 12. 
bolo está inscrito en un círculo perfecto, dentro del cual se ve la flor de loto, que habla de la meditación y la superación espiritual, y sobre ella un libro atestigua la importancia del conocimiento erudito.

En la Biblioteca Iberoamericana, en el gran fresco alegórico que ocupa la superficie del antiguo ábside, aparecen varios personajes históricos Entre ellos, Cristóbal Colón sostiene con ambas manos una gran esfera; aquí, como es obvio, la connotación que adquiere dicha esfera está relacionada con el globo terráqueo y la importancia de las proezas del navegante genovés.

En la obra de caballete encontramos en repetidas ocasiones, a personajes que sostienen una esfera, más pequeña y opaca que las anteriores. Hay que recordar que Montenegro practicó el retrato con éxito entre las personalidades de la época, por lo que son varios los ejemplos que existen al respecto. Sin embargo, considero que se trata de un elemento decorativo sin ulteriores significados, o en todo caso, no los he encontrado, como tampoco relación alguna entre ellos.

Hay dos retratos, sin embargo, que presentan esferas al lado de los retratados. Uno es el del pintor Jesús Reyes Ferreira y el otro del fotógrafo Hoyningen-Huene. En ellos las esferas son grandes y brillantes, reflejando parte del entorno. Por su brillantez, semejan un gran "ojo ciclópeo", como señala Olivier Debroise ${ }^{28}$ que realzara la importancia de la visión en los oficios de los retratados. Yo añadiría la multivisión que posee la facultad de crear universos mágicos a partir del reflejo del mundo de los objetos y de una determinada realidad, como es el caso de la labor de un artista plástico y de un fotógrafo.

Encontramos en los trabajos de lineamientos surrealistas, otro sentido dado a las esferas, que en ellos sugieren la presencia inquietante de fuerzas metafísicas e inexorables, dentro de una temática que alude frecuentemente al desastre y a la muerte.

Son todos estos significados los que conllevan las formas esféricas en la obra de Montenegro, a veces de manera explícita y elocuente, y otras matizados por elementos que conforman la obra en su totalidad. La esfera, como hemos visto, remite a conceptos de universalidad con connotaciones implícitas y dialécticas, de ciertas polaridades, tales como: principio - fin; conocimiento - hecatombe; infinito - efímero; eternidad - fragilidad; perfección - contingencia; ingravidez - movimiento; equilibrio - inestabilidad.

Hay entonces un sentido apocalíptico, ligado por dualidad al principio mismo de la vida $-\mathrm{y}$ todas las instancias ontológicas que, como amplio ${ }^{28}$ Ibidem. 
abanico, se abren entre ambos extremos--, sentido que parece ser la esencia última de estos elementos esféricos que constituyen un rasgo distintivo en el trabajo artístico de Roberto Montenegro, dotándolo a la vez de significados sutiles que aluden a fuerzas motrices primordiales, así como a valores permanentes en la vida del hombre. 